Bond University

Research Repository

\title{
Themes and prospects for intellectual property law reform
}

Arup, Christopher; van Caenegem, William

Published in:

Intellectual Property Policy Reform

DOI:

$10.4337 / 9781848449039.00006$

Licence:

CC BY-NC-ND

Link to output in Bond University research repository.

Recommended citation(APA):

Arup, C., \& van Caenegem, W. (2009). Themes and prospects for intellectual property law reform. In C. Arup, \& W. van Caenegem (Eds.), Intellectual Property Policy Reform: Fostering Innovation and Development (pp. 1-7). Edward Elgar Publishing. https://doi.org/10.4337/9781848449039.00006

\section{General rights}

Copyright and moral rights for the publications made accessible in the public portal are retained by the authors and/or other copyright owners and it is a condition of accessing publications that users recognise and abide by the legal requirements associated with these rights.

For more information, or if you believe that this document breaches copyright, please contact the Bond University research repository coordinator. 


\section{Bond University}

\section{ePublications@bond}

Law Faculty Publications

Faculty of Law

$1-1-2009$

\section{Themes and prospects for intellectual property law reform}

Christopher Arup

William van Caenegem

Bond University,william_van_caenegem@bond.edu.au

Follow this and additional works at: http://epublications.bond.edu.au/law_pubs

Part of the Intellectual Property Law Commons

\section{Recommended Citation}

Arup, Christopher and van Caenegem, William, "Themes and prospects for intellectual property law reform" (2009). Law Faculty Publications. Paper 301.

http://epublications.bond.edu.au/law_pubs/301

This Book Chapter is brought to you by the Faculty of Law at ePublications@bond. It has been accepted for inclusion in Law Faculty Publications by an authorized administrator of ePublications@bond. For more information, please contact Bond University's Repository Coordinator. 
Introduction

Themes and Prospects for Intellectual Property Law Reform

Chris Arup and William van Caenegem

When we set out to collect papers around our theme, we were encouraged by a mood of constructive criticism concerning the roles that intellectual property has come to play in innovation and creativity. Broadly the criticisms concern two developments: (1) the strength of intellectual property endowments and entitlements and (2) the proliferation and manipulation of claims to intellectual property rights (see Maskus and Reichman, 2004). The criticism largely comes from academic scholars and sets that community apart from practitioners who are perforce involved in pursuing the possibilities within the current laws.

The criticism is constructive. Very real questions remain about the social value of intellectual property, at least for some sectors of the economy and locations around the world. It is prudent to keep alternatives to intellectual property in mind when designing new policies, for there are many other ways that innovation and creativity can be furthered. Nonetheless, academic scholars are generally thinking of ways to improve intellectual property through the institution of reforms.

That is the flavour of our contributions. Essentially they pursue two lines. The first is for more rigour and discernment when deciding whether to confer intellectual property rights. This, it could be said, is merely to insist that intellectual property only reward efforts that are innovative and creative. The second is to influence how people use intellectual property rights, specifically how they transact in them. The aim is to encourage openness, once endowments have been made, in particular to promote coordination, circulation and sharing of intellectual property.

We are not alone in this approach, for intellectual property scholarship seems to be in a healthy condition. Our particular contribution comes from a workshop we convened on the Gold Coast in December of 2007. The participation was international, though we do appreciate that a majority of the contributors are Australian based. The Australian interest in intellectual property reform is very high.

What enables academic law scholars to identify and recommend reforms? Intellectual property scholarship forms part of a general trend within legal research to study the law 'in context'. Intellectual property is examined and assessed as it operates within empirically mapped social fields. 
The fields of interest range over industry sectors, creative clusters, contract networks, media subcultures, developing economies and public domains.

The contextualised approach is suited to reform. The contributors are able to ask whether intellectual property, as it is constituted, administered and put to use, is fulfilling the purposes ascribed to it. The context is changing. The conditions on which the old policies might properly have been based are being superseded. While the dominant model of corporate capitalism (large firm centralisation and internalisation) still fits some sectors and locations, the context changes with the onset of new technologies, business practices, work methods and social mores. If intellectual property is still an important security for investment in production, it must also facilitate dissemination and coordination of knowledge resources.

To work in context, legal researchers need to call on assistance from other disciplines. Our contributors are well read in other disciplines, which is not to say that they adopt the methods of those disciplines (such as economic modelling) or indeed that they are sufficiently expert to do so. Yet they are receptive to the insights those disciplines offer and increasingly they also seek empirical evidence to inform their recommendations. Thus, Peter Drahos goes inside patent offices; Dianne Nicol talks with start-up biotech companies; Janet Hope engages with creators of open licence systems; Ulf Petrusson and Caroline Pamp with builders of technology platforms.

While other disciplines have certain epistemological advantages over law, our experience suggests they will not always be as open-minded as lawyers are. For our contributors appreciate that law too forms part of social fields. In considering how legal agents influence the course of intellectual property, they have a rich and non-determinative sense of the possibilities of legal principles and legal processes. So Peter Drahos takes a close interest in patent office examiners, Charles Lawson in those commissioned to review competition policy, Ann Monotti in university technology transfer officers, and Joellen Riley in higher court judges.

If this research is neither traditional legal analysis, nor the method of another discipline, how should we characterise it? The contributors see intellectual property as forming part of the regulation and governance of innovation (see Anderson, 2006). So, they are interested in intellectual property in the hands of a variety of actors, including scientists, writers, artists, public institutes, universities, private firms, financial investors, government administrators, legal practitioners, legislators, judges and politicians. They seek to place intellectual property within a range of strategies or instruments of policy, some essentially outside law, but some varying within law as legislative directives, default 
principles, administrative guidelines, licence specifications, contractual terms or conditions attached to grants.

This approach is sceptical that one rule fits all. Policy making requires evidence that intellectual property will further innovation and creativity within a specific set of circumstances. William Kingston, Peter Drahos, Dianne Nicol, Hazel Moir and Charles Lawson all stress this point. Often, it will not do so directly. Instead, policy making should empower those individuals who want to work with intellectual property in this way. Janet Hope, Ulf Petrusson and Caroline Pamp, Ann Monotti, Matthew Rimmer, Megan Richardson and Jason Bosland, Joellen Riley, William van Caenegem and Chris Arup all express this preference.

So, what reforms do our contributors pursue? We said that they fall into two broad categories. The first, for rigour and independence, is when new rights are created. Much of the discussion is about regulating the criteria for appropriation, that is, the outer limits of the knowledge that should properly be the subject-matter of a patent or copyright right, or a non-disclosure or non-competition obligation. But our contributors also point to the need to be demanding when laws are being interpreted and applied to make individual grants.

It is appropriate that patents are a focus of this collection because they are amongst the most powerful of intellectual properties in the knowledge they encompass and the control they enable. Copyright is addressed in the context of the new media, a little less so than patents because of its coverage elsewhere. The contributions also take an interest in the appropriation of tacit knowledge, which, in the absence of trade secrets legislation, is decided by judges fashioning the scope of contractual and equitable obligations. This too is a live issue. Within a service economy, technical know-how and the emerging forms of intellectual and social capital, such as customer and workplace relations, are growing in value.

Hazel Moir take on the whole patent system, wanting patents to be confined to the situations where they make a difference - where they induce innovation that otherwise would not eventuate. Similarly, William Kingston wants to ensure that patents reward real investments in innovation not just the satisfaction of legal categories. Charles Lawson and William van Caenegem again are generally sceptical of grants: they want patents available only where they are needed to assist competition by lowering barriers to market entry and not, it follows, when they actually work anticompetitively. 
Moving down a layer into administration, Peter Drahos provides a detailed case why patent examiners in India should make their own rigorous assessments of applications from foreign companies, especially to avoid evergreening of pharmaceuticals. Dianne Nicol argues that, if patent rights are going to be strong, standards for granting patents should really insist on novelty, inventiveness and utility. Wiliam Kingston recommends a cheaper means of dispute resolution, technical arbitration, than litigation of patent validity through the courts. Joellen Riley counsels judges in Australia to think hard about the consequences of surrendering to the appeals of employers for property in information.

The uses made of intellectual property rights are our second target of reform. In this regard, regulatory reform does not so much direct how holders should exploit the intellectual property. It encourages and assists those who will use rights to expand innovation and open access. As these holders are regulating 'privately', the role required of the state is co-regulation or 'meta-regulation' - the regulation of regulation (Hope, Nicol and Braithwaite, 2008).

The basic settings of intellectual property law shape the uses made of it. Policy making involves decisions about which use rights will be conferred on the holders, which uses the holders may prevent others from pursuing or control in other ways. Megan Richardson and Jason Bosland pursue this regulation through the recurring contest, largely in the courts, over the scope of the fair use provisions of copyright. Their case study is the revival of an old medium of expression, street news, now manifested in a new electronic internet form. They argue that the street news use of newspaper copy should not have to be 'transformative'.

Several contributions make the initial rights holders the subject of their study. The chapters are interested in those who do not want to use their rights to lock down intellectual property, but who wish to construct open licensing systems. This focus is recognition that the context is changing, that much innovation and creativity are network-based or even the outcome of an all comers knowledge bazaar or a commons-based peer production. They stress the interactive, roundabout, cumulative nature of innovation.

As systems engineers, these holders are taking their own steps to work around the hold-ups and break-downs associated with strong entitlements and micro-protection of rights, as we see for example in patent thickets and a welter of copyright take-down notices. Such reciprocating and coordinating systems are largely self-generating; they are movements that are growing organically. At the same time, they are quite regulatory. Their protocols and mores are so sophisticated that 
some go as far as to consider them constitutions (see Jorges, Sands and Teubner, 2004). But this belies their fragility. They also need a supportive public law environment in which to prosper.

At this stage, they are most pronounced in the media sectors where copyright is the main intellectual property governor. Matthew Rimmer explains the dynamics of a successful system par excellence, Wikipedia, though he has his fingers crossed that copyright litigation will not foul it up. Its integrity depends principally on people's discretion and restraint. If litigation is being brought, it will call for a sympathetic reception from the courts, sitting possibly anywhere in the world, and remedial action by legislatures if the judicial environment turns hostile.

Both the Janet Hope and the Ulf Petrusson and Caroline Pamp contributions point the way for similar systems or platforms to develop in the biotechnology/biomedicine patents sectors. The organisational innovations they recommend are perhaps not as wide open as the Wikipedia model. But they are more accessible than other collective responses in the past such as industry patent pools and relational contracting (Dreyfuss, Zimmerman and First, 2001). These contributions envisage how intellectual property can be used for increasing the openness of innovation, citing examples that are working. Open licensing systems are crucial to avoiding lock-up of resources by upstream owners and break-downs in exchange because there are so many rights holders.

Subject to their universities' policies, university researchers can be involved in these open licensing systems. Ann Monotti captures them in more conventional intellectual property roles. They have become more like private holders, perhaps of necessity. Yet the right policies can encourage university decision makers to release the intellectual property they are not using and to seek out those licensees who want to work the inventions. Regulatory studies offers tools and Monotti identifies them at work in the proactive United States approach, including the legislative directives of the Bayh-Dole Act, the conditions the National Institutes place on money grants and the collegiate universities' code of ethics for research.

This perspective on the universities reminds us that intellectual property is mainly transacted in the commercial world. Nonetheless, as Benkler (2006) explains, the commercial interests that people show in intellectual property can vary. They can be commercial without being proprietary. Some are more positive for innovation. Rights can be used negatively against innovation. For example, litigation might be threatened to increase risks and costs, to bar others entry, to extract rents.

As Dianne Nicol finds, not everyone uses intellectual property this way. The first policy reflex is to be cautious about conferring rights at all, allowing freedom to operate. But if conferring rights is a 
positive, then policy should be concerned with who gets rights and what they do with them. Thus, Dianne Nicol argues that innovation is furthered if small biotech companies have some command of intellectual property; likewise Joellen Riley, William van Caenegem and Chris Arup if workers do.

The final bunch of contributions to the book sees mobile individual workers as keys to the dissemination and recombination of knowledge. Large firms need some reward for the economies of scale and scope they bring to innovation. But increasingly innovation benefits from circulation either within localised networks (the high point being Silicon Valley) or inter-national movement of knowledgeable and skilled people. 'Freed up' by organisational changes, the hollowing out of the large firms, these workers want to take intellectual property rights with them to other firms or to their own start-ups and collectives. Systems prosper if these individuals have incentives to invest in intellectual and social capital. Some of that investment returns to their first firm. However, workers should be free to put knowledge to new uses elsewhere.

What intellectual property policy is conducive to mobility? Again policy begins with a caution against over-appropriation. Where ownership can be justified, the question is who is to be free to use the rights to the knowledge. The property in question can be the rights to use explicit or codified knowledge - such to work patents. In this regard, Chris Arup's contribution considers whether it is good policy to split entitlements between employers and workers and between principals and consultants. Just as vital to innovation is the right to use tacit knowledge. In their contributions, Joellen Riley and William van Caenegem seek the appropriate limits to the scope and application of civil obligations, the non-disclosure and non-competition restraints that the judges will uphold as a matter of contract and equity. In these relationships, intellectual property and freedom of contract should be moderated by a common law competition law.

In some jurisdictions, competition law becomes a legislative and administrative scheme. Competition law has the potential to allow for intellectual property while correcting for some of its abuses. That allowance can be on a categorical basis or a more searching case-by-case basis. On the basis of an Australian experience, Charles Lawson wonders if competition law policy makers have the will to regulate the uses made of intellectual property by those with market power, such as the restrictive conditions inserted into licences (where licences are given at all). Joellen Riley asks the judges recall the common law's aversion to restraints of trade, especially before giving employers the procedural advantage of an interim injunction.

While disposed to variety, our contributors do not suggest that intellectual property should be left entirely to the market. There is attraction in the argument that innovation is much too complex and 
unpredictable for it to be engineered socially. However, the final policy position is not one of pure freedom of contract or absolute contract autonomy. The market is already regulated when intellectual property is created. Our contributors do lean towards voluntarism when it comes to the deployment of intellectual property rights. They are showing faith that holders will be interested in promoting innovation and creativity. But the framework still matters and public regulation is still needed - at the pointy end of the regulatory pyramid - if rights are abused. One danger with contract autonomy is that the powerful will obtain more than their legal entitlement.

But is it worth entertaining such reforms - or have the possibilities been foreclosed? One check on our enthusiasm is the extent of intellectual property standardisation internationally. The WTO TRIPS agreement is a high point of standardisation. Checks on reform are also to be found in bilateral inter-governmental agreements and in memoranda of understandings between functional regulators such as the patent offices. Standardisation reduces the freedom to experiment with intellectual property regulation and to choose divergent legal paths. That includes the opportunity to learn from the experience in other jurisdictions, to avoid the same mistakes or simply to adapt the form to different local conditions.

Yet we could pitch reform efforts at the international level. The international level provides another political and legal space into which to make reform efforts. If standardisation proceeds, the content of it is still contested, both within, and between, international organisations. Some aspects of intellectual property are not as standardised as others. They include trade secrets, employee inventions, moral rights, and the regulation of the distributions and uses of rights, including competition law - the second of the two broad pursuits of this book. Even the more established aspects of regulation, like the criteria for patents and copyright endowments, reveal gaps in coverage and explicit allowances for choices to be made at the national level. So, despite their own protestations at times, national leaders have opportunities. Their policies can be demanding of any grant of intellectual property endowments, geared to openness in the regulation of uses, and tailored to the conditions for local innovation and creativity. The failure to do so is often the result of domestic politics of interest or eagerness to please international constituencies, not the imagination of alternatives. 
References

Andersen, B. (ed) (2006), Intellectual Property Rights: Innovation, Governance and Institutional Environment Cheltenham, UK and Northampton MA, US: Edward Elgar.

Benkler, Y. (2006), The Wealth of Networks: How Social Production Transforms Markets and Freedom, New Haven and London: Yale University Press.

Dreyfuss, R., D. Zimmerman and H. First (eds) (2001), Expanding the Boundaries of Intellectual Property: Innovation Policy for the Knowledge Society, Oxford: Oxford University Press.

Hope, J., D. Nicol and J. Braithwaite (2008), 'Regulatory Capitalism, Business Models and the Knowledge Economy', in Braithwaite, J., Regulatory Capitalism, Cheltenham, UK and Northampton MA, US: Edward Elgar.

Joerges, C., I-J. Sand and G. Teubner (eds) (2004), Transnational Governance and Constitutionalism, Oxford: Hart Publishing.

Maskus, K. and J. Reichman (eds) (2005), International Public Goods and Transfer of Technology under a Globalized Intellectual Property Regime, Cambridge: Cambridge University Press. 